\title{
ANALISIS PENANGANAN PENERIMAAN TANDAN BUAH SEGAR PADA PT. BIO NUSANTARA TEKNOLOGI DI KECAMATAN PONDOK KELAPA KABUPATEN BENGKULU TENGAH
}

\section{Unloading Handling System of Fresh Fruits Bundling in PT Bio Nusantara Teknologi in Subdistrict of Pondok Kelapa District of Bengkulu Tengah}

\author{
January Rizki, Nusril, dan Putri Suci Asriani \\ Jurusan Sosial Ekonomi Pertanian Fakultas Pertanian Universitas Bengkulu
}

\begin{abstract}
This paper aimed to determine the handling system receiving TBS in PT.Bio Nusantara Teknologi to three supplier of partners supplier, plasma supplier and general supplier and how opportunities for improvement that can be done. This study used decriptive analysis and F test to examined wether there is discrimination in handling treatment and price of TBS among suppliers. The results showed that there are several steps that must be passed TBS suppliers to sell it to the POM: 1) taking a queue number, 2) The calling queue number, 3) Weighing, and 4) Sorting and loading and unloading. There was no difference in the treatment of the company against a third supplier, but the difference is the quality of fruit that would affect the price. The price difference was tested using the Tukey's test or BNJ. From the results of the research sequence starting price of the highest rates of plasma suppliers, partners supplier and then general supplier.
\end{abstract}

Keywords: Handling system, TBS price, suppliers

\section{PENDAHULUAN}

\section{Latar Belakang}

Kelapa sawit merupakan salah satu primadona tanaman perkebunan, yang menjadi sumber penghasil devisa non-migas bagi Indonesia.Kelapa sawit merupakan perkebunan penting di Indonesia dan masih memiliki prospek yang cerah, komoditas kelapa sawit baik berupa minyak mentah maupun hasil olahannya menduduki peringkat ke-3 penghasil devisa non migas setelah karet dan kopi (Priyono, 2008). Dari berbagai perkembangan dan kajian yang ada, terlihat bahwa ke depan persaingan dalam usahaperkebunan kelapa sawit 
bukan saja terjadi antar sesama negara produsen melainkan juga persaingandengan jenis minyak nabati lainnya. Hal ini jelas terlihat dari gambaran tentang pangsa konsumsidan produksi minyak nabati terlihat pada Tabel berikut:

Tabel 1. Pangsa Produksi dan Konsumsi Minyak Nabati Dunia (ton)

\begin{tabular}{llrrrr}
\hline No & \multicolumn{1}{c}{ Uraian } & $\mathbf{1 9 9 3 - 1 9 9 7}$ & $\mathbf{1 9 9 8 - 2 0 0 2}$ & $\mathbf{2 0 0 3 - 2 0 0 7}$ & \multicolumn{1}{c}{$\mathbf{2 0 0 8 - 2 0 1 2}$} \\
\hline & I.Total Produksi & $\mathbf{7 0 . 7 7 8 . 0 0 0}$ & $\mathbf{8 3 . 6 8 0 . 0 0 0}$ & $\mathbf{9 5 . 6 2 4 . 0 0 0}$ & $\mathbf{1 0 8 . 5 1 2 . 0 0 0}$ \\
1. & M. sawit & 15.500 .382 & 20.752 .640 & 25.340 .360 & 29.949 .312 \\
2. & M. Kedelai & 17.765 .278 & 19.915 .840 & 22.376 .016 & 25.174 .784 \\
3. & M. kanola & 10.121 .254 & 11.966 .240 & 12.526 .744 & 15.517 .216 \\
4. & M. bunga matahari & 8.351 .804 & 9.790 .560 & 12.526 .744 & 12.044 .832 \\
5. & M. lainnya & 19.039 .282 & 21.254 .720 & 22.854 .136 & 25.825 .856 \\
& II.Total Konsumsi & $\mathbf{9 0 . 5 0 1 . 0 0 0}$ & $\mathbf{1 0 4 . 2 8 1 . 0 0 0}$ & $\mathbf{1 1 8 . 0 6 1 . 0 0 0}$ & $\mathbf{1 3 2 . 2 3 4 . 0 0 0}$ \\
1. & M. sawit & 15.385 .170 & 20.021 .952 & 25.973 .420 & 29.752 .650 \\
2. & M. Kedelai & 17.828 .697 & 20.126 .233 & 22.313 .529 & 25.124 .460 \\
3. & M. kanola & 10.045 .611 & 11.783 .753 & 13.577 .015 & 15.471 .378 \\
4. & M. bunga matahari & 8.326 .092 & 9.593 .852 & 10.861 .612 & 12.033 .294 \\
5. & M. lainnya & 38.915 .430 & 42.755 .210 & 45.335 .424 & 49.852 .218 \\
\hline
\end{tabular}

Sumber : diolah dari Oil World (2011)

Jika ditinjau untuk masing-masing komoditi, diperoleh gambaran bahwa pertumbuhan produksiuntuk minyak kelapa sawit pada periode 2003-2007 mengalami kenaikan menjadi 25.340 .360 ton $(26,5 \%)$ dari total produksi jenis minyak nabati. Mulai periode 2003-2007 pangsa konsumsi minyak kelapa sawit mengungguli pangsa konsumsi minyak kedelai. Kondisi tersebut diperkirakan masih akan terus berlanjut hingga tahun 2020 (Anonim, 2011).

Kelapa sawit merupakan tumbuhan tropis yang termasuk tanaman tahunan dan digunakan untuk keperluan industri, baik untuk indutri minyak goreng, industri minyak olahan, dan industri bahan lainnya yang akan terus meningkat sesuai dengan penambahan penduduk. Meningkatnya pendapatan penduduk mendorong peningkatan bahan mentah berupa minyak Crude Palm Oil (CPO) untuk diproduksi. Bahan baku CPO adalah tandan buah segar (TBS) (Naibaho, 1996).

Dalam tigapuluh tahun terakhir, jumlah konsumsi minyak nabati di seluruh dunia meningkat tiga kali lipat. Diantara komoditas utama minyak nabati, minyak kelapa sawit meraih tingkat pertumbuhan paling tinggi. Produksinya mencapai sepuluh kali lipat, sehingga besarnya jumlah konsumsi minyak kelapa sawit diantara minyak nabati lainnya telah mencapai 34 persen yang tadinya hanya 11 persen. Bahkan kalau produksi minyak biji sawit ikut 
dihitung, maka besarnya mencapai 38 persen (Teoh, 2010 dalam anonim, 2011).Menurut Ketua Umum Gabungan Pengusaha Kelapa Sawit Indonesia (Gapki) Joefly J Bahroeny, komoditas kelapa sawit dan turunannya ternyata menyumbang devisa cukup besar. Pada 2010, komoditas ini menyumbang devisa US\$ 14,1 miliar atau sekitar Rp 122,7 triliun. Kelapa sawit mampu menghasilkan sedikitnya 2,5 ton minyak kelapa sawit mentah per hektar per tahun dengan biaya produksi US\$300. Minyak kedelai, pesaing utama CPO, hanya menghasilkan 1 ton minyak perhektar per tahun dengan biaya US\$ 500 . Indonesia memproduksi 21,6 juta ton CPO dari lahan seluas 7,9 juta hektar dan mengekspor 15,5 juta ton pada 2010.

Menurut Pahan (2007) keragaman kualitas minyak kelapa sawit ditentukan oleh kegiatan panen, transportasi, pengolahan dan penimbunan. Produksi minyak sawit mentah merupakan rangkaian kegiatan yang diawali dengan mengolah tandan buah segar. TBS yang dengan kualitas baik maka akan menghasilkan CPO yang baik pula. Bahan baku TBS ini dapat diperoleh dari kebun inti milik perusahaan sendiri atau membelinya dengan pihak ketiga. Pembelian bahan baku ini dilakukan agar dapat memenuhi kapasitas produksi CPO oleh perusahaan.

Kegiatan pembelian merupakan aktivitas utama dari perusahaan untuk menyediakan bahan baku yang digunakan dalam proses produksi. PT. Bio Nusantara Teknologi Kabupaten Bengkulu Tengah merupakan perusahaan swasta yang bergerak di bidang pertanian yaitu subsektor perkebunan komoditi kelapa sawit dengan satu unit pabrik pengolahan kelapa sawit berkapasitas 30 ton/jam. Pabrik pengolahan minyak kelapa sawit PT. Bio Nusantara Teknologi mengolah Tandan Buah Segar (TBS) menjadi Crude Palm Oil (CPO) dan inti sawit yang dapat dipasarkan langsung ke perusahaan yang mengolah CPO menjadi produk lain seperti minyak goreng dan mentega.

Bahan baku TBS pada PT. Bio Nusantara Teknologi diperoleh dari kebun inti milik perusahaan dan juga berasal dari pihak ketiga yaitu plasma, mitra dan umum, namun yang hanya pemasok dari pihak ketiga yang mengikuti alur antrian, sedangkan pemasok dari kebun inti langsung masuk tanpa mengantri. Ada beberapa tahapan sistem penanganan yang dilakukan oleh perusahaan dalam proses penerimaan bahan baku TBS. Untuk memasuki tahapan-tahapan tersebut para pemasok TBS harus mengikuti alur antrian agar dalam penanganan penerimaan ini berlangsung baik. Sehingga perusahaan harus memiliki pelayanan yang baik pula agar pihak pemasok bahan baku TBS dapat dengan lancar pada saat penanganan penerimaan bahan baku.

Pemasok bahan baku umum menjual TBS ke perusahaan biasanya tergantung harga yang ditawarkan oleh perusahaan. Pemasok mitra harus tetap menjual TBS ke perusahaan karena sudah ada ikatan kontrak. Pemasok plasma, buah yang dijual sudah harus sesuai dengan standarisasi perusahaan. Adanya perbedaan sumber pasokan TBS ini memungkinkan terjadinya 
perbedaan penanganan penerimaan dan harga yang dilakukan oleh perusahaan .

Berdasarkan uraian pada bagian latar belakang maka penelitian ini bertujuan untuk (a) mengetahui sistem penangan penerimaan TBS, (b) mengetahui apakah ada perbedaan harga TBS terhadap pemasok mitra, umum, dan plasma, serta (c) mengetahui peluang perbaikan penanganan penerimaan TBS yang dapat dilakukan oleh PT.Bio Nusantara Teknologi sekarang ini.

\section{METODE PENELITIAN}

\section{Penentuan Lokasi dan Waktu Penelitian}

Penelitian ini dilakukan di PT.Bio Nusantara Teknologi yang berlokasi di Desa Tanjung Sakti, Kecamatan Pondok Kelapa, Kabupaten Bengkulu Tengah. Penentuan lokasi ini dilakukan secara sengaja (purposive) dengan pertimbangan bahwa PT. Bio Nusantara Teknologi merupakan salah satu perusahaan pertanian subsektor kelapa sawit memenuhi kebutuhan bahan bakunya tidak hanya berasal dari kebun inti tetapi juga dipasok dari perkebunanan rakyat yang dikelompokan menjadi 3 (tiga) kelompok pemasok yaitu plasma, mitra dan umum.

\section{Metode Penentuan Responden}

Pengambilan responden pada penelitian ini yaitu dilakukan secara purposive (dengan sengaja), yaitu terdiri dari karyawan/petugas yang bertugas pada setiap tahap penanganan penerimaan TBS yaitu pada bagian pengambilan nomor antri, penimbangan dan sortasi di PT. Bio Nusantara Teknologi serta sopir pembawa kendaraan pengangkut TBS. untuk responden sopir diambil berdasarkan sebaran waktu yaitu pagi, siang dan sore. Masingmasing diambil 1 (satu) dari setiap pemasok, yaitu pagi diambil 3 (tiga) responden yaitu pemasok plasma, umum dan mitra. Siang diambil 3 reponden yaitu pemasok plasma, mitra, dan umum dan sore diambil 3 responden yaitu mitra, plasma dan umum.

\section{Metode Pengumpulan Data}

Data yang dikumpulkan terdiri dari data primer dan data sekunder. Data primer diperoleh secara langsung dari responden melaui wawancara dengan supir dan petugas disetiap bagian penanganan penerimaan TBS menggunakan kuisioner yang disiapkan Data ini meliputi deskripsi objek penelitian meliputi berat dan harga TBS, persentase tenera, TBS yang dipulangkan (supir), tugas petugas di setiap bagian penanganan penerimaan TBS, kendala yang dihadapi saat penanganan, dan lainnya (petugas) serta data lainnya yang berkaitan dengan penelitianini. Data sekunder diperoleh dari berbagai literatur atau 
pustaka dan instansi yang berkaitan dengan penelitian ini, yaitu data nama dan jumlah pemasok mitra, plasma dan umum yang terdaftar pada bulan juli 2011, data jumlah maksimal kendaraan untuk pemasok mitra, plasma dan umum (PT.Bio Nusantara Teknologi).

\section{Metode Analisis Data}

\section{Analisis Deskripsi}

Analisis deskriptif digunakan untuk mengetahui sistem penanganan penerimaan Tandan Buah Segar (TBS) pemasok plasma, mitra dan umum yang dilakukan pada PT. Bio Nusantara Teknologi. Analisis deskriptif ini juga digunakan untuk menganalisis peluang perbaikan penannganan penerimaan TBS di PT.Bio Nusantara Teknologi. Analisis penanganan penerimaan dan peluang perbaikan dilakukan secara deskriptif karena menjelaskan secara menyeluruh dari apa yang dilihat secara nyata. Analisis deskriptif digunakan untuk menjelaskan secara menyeluruh data yang diperoleh.

\section{Analisis Uji beda Rata-Rata HargaTBS Plasma, Mitra, dan Umum}

Perbedaan penanganan penerimaan antara plasma, mitra dan umum akan menyebabkan perbedaan harga antara ke-3 (tiga) pemasok tersebut. Analisis perbedaan harga ini dilakukan dengan uji Beda Nyata Jujur (BNJ) atau uji Tukey HSD. Prosedur pengujian dengan uji tukey HSD adalah sebagai berikut:

a. Uji sidik ragam (anova):

- $\quad \mathrm{FK}=\mathrm{Tij} 2 /$ r.p

- Jumlah Kuadrat Pemasok $(\mathrm{JKP})=\sum_{i}^{p} \sum_{j}^{u}\left(\bar{Y}_{i} \cdot-\bar{Y}_{. .}\right)^{2}$

- Jumlah kuadrat total (JKT) $=\sum_{i}^{p} \sum_{j}^{u}\left(Y_{i j}-\bar{Y}_{\text {... }}\right)^{2}$

- Jumlah kuadrat galat $(\mathrm{JKG})=\mathrm{JK}$ total $-\mathrm{JK}$ pemasok

Tabel 3. Sidik Ragam

\begin{tabular}{|c|c|c|c|c|c|}
\hline \multirow{2}{*}{$\begin{array}{l}\text { Sumber } \\
\text { Keragaman }\end{array}$} & \multirow{2}{*}{$\begin{array}{c}\text { Derajat } \\
\text { Bebas }(\mathrm{db})\end{array}$} & \multirow{2}{*}{$\begin{array}{c}\text { Jumlah } \\
\text { Kuadrat (Jk) }\end{array}$} & \multirow{2}{*}{$\begin{array}{c}\text { Kuadrat } \\
\text { Tengah(Kt) }\end{array}$} & \multirow{2}{*}{$\begin{array}{c}\text { F } \\
\text { hitung }\end{array}$} & F tabel \\
\hline & & & & & $5 \%$ \\
\hline Pemasok & $(\mathrm{p}-1)$ & JKP & $\mathrm{JKP} /(\mathrm{p}-1)$ & & \\
\hline Galat & $\mathrm{P}(\mathrm{u}-1)$ & JKG & $J K G /(p u-p)$ & & \\
\hline Total & $(\mathrm{pu}-1)$ & JKT & & & \\
\hline
\end{tabular}

110 | January Rizki, Nusril, dan Putri Suci Asriani, Analisis Penanganan ... 
b. Menghitung koefisien keragaman untuk menentukan uji lanjutan yang harus digunakan.

Dengan rumus: $\mathrm{KK}=\frac{\text { KTGalat }}{y} \times 100 \%$

c. Mmenghitung nilai baku dari BNJ dengan rumus sebagai berikut:

$$
B N J_{\alpha}=q_{(p, v, \alpha)} \cdot \sqrt{\frac{K T \text { galat }}{r}}
$$

dimana $\mathrm{P}=$ permasok, $\mathrm{v}=$ derajat bebas, $\mathrm{a}=$ persentase taraf nyata $(1 \%=0,001$ atau $5 \%=0,005), \mathrm{u} \quad=$ kelompok

Nilai $q(p, v, a)$ dilihat pada tabel nilai kritis ujiperbandingan berganda Tukey pada taraf nyata $1 \%$ dan $5 \%$. Nilai $q(p, v, a)$, ditentukan berdasarkan nilai taraf nyata yang dipilih.

d. Menentukan perbedaan pengaruh antarperlakuan. Untuk ini digunakan kodefikasi dengan huruf.

Caranya adalah sebagai berikut:

i. Di susun nilai rata-rata perlakuan dari yang terkecil hingga yang terbesar.

ii. Ditentukan huruf $(\mathrm{a}, \mathrm{b}, \mathrm{c}, \mathrm{d})$ pada nilai rata-rata tersebut.

Setelah ditetapkan huruf-huruf (a, b, c, d) tersebut, disusun kembali nilai rata-rata perlakuan tersebut. Pemasok yang diikuti oleh huruf yang sama berarti tidak berbeda nyata pengaruhnya.

\section{HASIL DAN PEMBAHASAN}

\section{Sistem Penanganan Penerimaan TBS}

Penerimaan TBS di PT.Bio Nusantara Teknologi Bengkulu dilakukan setiap hari selama 24 jam. Sehingga kapanpun pemasok ingin menjual TBS ke pabrik akan selalu buka. Namun ada beberapa hal yang menyebabkan pabrik tutup untuk sementara, yaitu apabila sedang ada kerusakan pada mesin pengolahan dan kondisi diloading ramp sedang penuh. Dengan demikian pabrik terpaksa menutup sementara proses penerimaan TBS dari semua pemasok untuk memperlancar kegiatan di pabrik.

Pemasok TBS

TBS pada PT. Bio Nusantara Teknologi selain dari kebun inti tetapi juga berasal dari pemasok-pemasok TBS, namun yang pemasok dari kebun inti tidak ikut mengantri dalam proses penerimaan TBS. Di PT.Bio Nusantara 
Teknologi ini pemasok TBS dibagi menjadi 3 (tiga) kelompok yaitu mitra murni, mitra plasma dan pemasok umum. Ketiga pemasok inilah yang akan mencukupi bahan baku produksi yang dibutuhkan PT. Bio Nusantara Teknologi karena TBS yang berasal dari kebun sendiri belum cukup memenuhi kapasitas mesin pengolahan. Kebun perusahaan hanya mampu menghasilkan TBS antara 11,350 kg-173.190 kg TBS/hari dan dapat memenuhi kebutuhan TBS sebesar 18,19 \% TBS sedangkan kapasitas mesin pabrik mencapai 30 ton/jam, sehingga dalam sehari untuk memenuhi kapasitas pabrik setidaknya memerlukan \pm 720 ton/hari. Untuk mencukupi kebutuhan mesin pabrik maka PT.Bio Nusantara Teknologi membeli TBS dari pihak ketiga. Selain itu pembelian TBS dari luar atau pihak ke tiga khususnya mitra murni dan mitra plasma juga bertujuan untuk menghasilkan kualitas CPO yang lebih baik untuk menutupi pasokan TBS dari pemasok umum.

Dalam periode 3 (tiga) bulan sekali perusahaan memberikan penghargaan kepada pemasok baik itu pemasok mitra, plasma ataupun umum. Penghargaan ialah sesuatu yang diberikan pada perorangan atau kelompok jika mereka melakukan suatu keulungan di bidang tertentu (Wikipedia). Keulungan yang dilakukan oleh pemasok ini yaitu dinilai berdasarkan volume TBS yang masuk ke PT.Bio Nusantara Teknologi. Penghargaan tidak selamanya berbentuk uang namun juga dapat berupa barang atau sertifikat dan jenis lainnya. Begitu pula yang diterapkan di PT.Bio Nusantara Teknologi, penghargaan yang diberikan yaitu berupa barang seperti barang elektronik. Pemberian penghargaan ini merupakan strategi yang baik untuk menyemangati pemasok agar dapat menjual TBS dengan volume yang banyak dan kualitas yang baik pula.

\section{a. Mitra murni}

Pemasok mitra murni biasa disebut pemasok mitra. Pemasok mitra murni merupakan pemasok yang memiliki kerjasama dengan PT.Bio Nusantara Teknologi. Dimana pemasok harus memasok atau menjual seluruh hasil TBS ke PT.Bio Nusantara Teknologi karena pihak mitra telah memiliki kontrak dengan perusahaan. Kontrak telah disetujui sebelum pemasok menjadi mitra PT.Bio Nusantara Teknologi Bengkulu. Keuntungan menjadi mitra yaitu memperoleh harga TBS yang lebih tinggi dibanding dengan pemasok umum, namun ada syarat atau ketentuan yang ditetapkan oleh perusahaan, yaitu pemasok mitra harus memiliki TBS dengan persentase buah tenera sebesar $>60 \%$. Karena semakin besar persentase tenera maka akan semakin baik kualitas CPO yang dihasilkan.

Jumlah TBS mitra yang masuk ke PT.Bio Nusantara Teknologi pada bulan Juli 2011 yaitu sebanyak $7.605 .640 \mathrm{~kg}$ dan berkisar antara $112.450 \mathrm{~kg}$ - $358.010 \mathrm{~kg}$ TBS/hari, dengan jumlah TBS sebesar itu dan kualitas yang sesuai dengan stardarisasi perusahaan, pemasok mitra dapat membantu $41,96 \%$ dari total seluruh TBS yang masuk untuk memenuhi jumlah TBS yang dibutuhkan PT.Bio Nusantara Teknologi.

112 | January Rizki, Nusril, dan Putri Suci Asriani, Analisis Penanganan ... 
Pembelian TBS yang dilakukan oleh PT.Bio Nusantara Teknologi adalah dengan syarat pembelian FOB Destination,yaitu barang yang dibeli diakui dan dapat dibayar setelah barang tersebut telah berada digudang atau di Pabrik Minyak Kelapa Sawit (PMKS) milik PT.Bio Nusantara Teknologi.

Untuk menjadi mitra murni para petani harus memiliki kebun sendiri. Pemasok mitra ini direkrut oleh perusahaan karena memiliki kualitas buah yang baik yaitu memiliki persentase tenera $>60 \%$. Para petani atau pemilik kebun nantinya akan mendapat binaan yang dilakukan oleh pihak perusahaan. Binaan dilakukan perusahaan sebanyak 2 kali seminggu. Namun jika mitra memiliki keluhan terhadap hasil panen dan menginginkan pihak perusahaan meninjau, maka pihak perusahaan akan meninjau kelokasi di luar jadwal pembinaan.

Pemasok mitra pada PT. Bio Nusantara Teknologi berasal dari berbagai daerah. Dari data yang diperoleh peneliti ada 12 (dua belas) mitra yang memiliki nomor DO (Delivery Order) yang berasal dari Pino, Talo, Bengkulu Utara, Bengkulu Tengah, Seluma dan daerah-daerah lain. Pemasok mitra bukan saja petani yang memiliki kebun tetapi juga perusahaan-perusahaan perkebunan kelapa sawit yang tidak memiliki pabrik sendiri. Luas lahan yang dimiliki pemasok mitra ini antara 80 ha s/d 600 ha. Total luas lahan yang dimiliki petani mitra yaitu 2130 ha dengan rata-rata luas lahan 177,5 ha.

\section{b. Mitra Plasma}

Pemasok mitra plasma biasanya disebut pemasok plasma. Pemasok plasma merupakan petani kelapa sawit yang berada di Desa sekitar PT. Bio Nusantara Teknologi. Petani plasma mendapatkan bantuan kredit bibit sehingga TBS yang dihasilkan akan sesuai dengan standarisasi perusahaan yaitu memiliki varietas tenera $>60 \%$. Bantuan kredit ini kan dibayar petani setelah pemasok plasma menjual hasil panen ke perusahaan. Selain mendapat bantuan bibit, plasma juga diberi binaan oleh PT. Bio Nusantara Teknologi.

Pembinaan oleh perusahaan dilakukan selama dua kali dalam sebulan yaitu 2 (dua) minggu pertama dan 2 (dua) minggu berikutnya secara bergantian untuk setiap anggota plasma. Sama halnya dengan pemasok mitra murni, jika petani memiliki keluhan atau kendala pada saat pemanenan atau hasil buah TBS dan menginginkan pihak perusahaan meninjau ke lapangan maka pihak perusahaan bersedia datang walaupun diluar hari pembinaan yang telah ditentukan.

Pemasok plasma harus menjual TBS keperusahaan karena telah terikat kontrak. Maka dari itu pihak perusahaan selalu mengontrol ke petani langsung pada saat pembinaan. Pengontrolan dilakukan bertujuan agar apabila ada kendala yang dihadapi pemasok baik yang berkaitan dapat segera diatasi.Plasma yang terdaftar di PT. Bio Nusantara Teknologi berjumlah 14 pemasok dan memiliki nomor DO (Delevery Order). Luas lahan yang dimiliki setiap pengolah lahan oleh petani plasma yaitu antara11,75 ha s/d 62 ha. Rata-rata luas lahan 2871 ha dan jumlah 
pasokan TBS yang masuk ke PT. Bio Nusantara Teknologi pada bulan Juli 2011 yaitu sebesar $347.220 \mathrm{~kg}$ yang berkisar antara $2.900 \mathrm{~kg}-21.780 \mathrm{~kg}$ TBS/hari, dengan jumlah sebesar ini petani plasma mampu memenuhi kebutuhan PT. Bio Nusantara Teknologi sebesar 1,91 \%dari total keseluruhan TBS pada bulan ini. Pemasok TBS paling sedikit memasok TBS ke perusahaan namun ini cukup membantu karena kualitas TBS sudah cukup baik karena telah memenuhi kriteria standarisasi PT. Bio Nusantara Teknologi.

\section{c. Pemasok umum}

Pemasok umum merupakan petani sawit, tengkulak atau perekebunan lain yang menjual TBSnya berdasarkan harga yang ditetapkan perusahaan. Pemasok umum tentunya akan memilih menjual TBSnya ke pabrik yang menetapkan harga yang tinggi dan sesuai dengan biaya pengangkutan ke pabrik yang tidak akan merugikan mereka. Pemasok umum tidak harus menjual TBSnya ke PT. Bio Nusantara Teknologi karena pemasok umum tidak memiliki kontrak atau perjajian kerjasama dengan PT. Bio Nusantara Teknologi. Namun dilihat dari data yang diperoleh dari perusahaan kualitas TBS dari pemasok umum kurang baik karena jenis buah tenera lebih sedikit dibanding jenis buah dura yaitu antara $14 \%$ - 34\%.

Pada bulan Juli 2011 jumlah TBS umum yang masuk ke PT.Bio Nusantara Teknologi sebesar $6.871 .670 \mathrm{~kg}$ dan berkisar antara $105.330 \mathrm{~kg}-324.490 \mathrm{~kg}$ TBS/hari. Pasokan TBS dari pemasok umum ini mampu membantu memenuhi kebutuhan PMKS sebesar 37,91\% yang berarti pemasok umum merupakan pemasok terbesarkedua setelah pemasok mitra pada bulan Juli 2011 ini.

\section{Persyaratan Penerimaan TBS}

Ada beberapa perjanjian kerjasama antara perusahaan dan pihak kedua PT. Bio Nusantara Teknologi yang harus dipatuhi oleh pemasok atau pihak kedua. Adapun persyaratan penerimaan yang ditetapkan oleh PT.Bio Nusantara Teknologi Bengkulu, yaitu:

1. Jika pihak kedua sebagai petani perkebunan maka wajib memiliki surat eterangan dari kepala desa setempat untuk menyatakan memang benar memiliki kebun kelapa sawit dengan luas areal dan tahun tanam yang dituangkan dalam surat keterangan tersebut, jika berbentuk koperasi atau badan usaha lainnya maka wajib melampirkan surat izin usaha serta data areal petani pekebun binaan baik luas areal maupun tahun tanamnya dan bila sebagia pedagang pengumpul yang memiliki izin usaha wajib melampirkan surat usaha serta memiliki data asal TBS dan tahun tanam lalu kepada Perusahaan sebagai jaminan legalitas TBS yang diterima dari pihak kedua.

2. Sebagai persyaratan administrasi akan pihak kedua atau pemasok wajib menyerahkan kepada perusahaan berupa: (a) Permohonan kontrak, (b) Copy kartu tanda Penduduk (KTP), (c) Pas foto $3 \times 4$ (hitam putih), (d) Surat keterangan dari kepala desa, dan (e) Materai 
3. Setiap pengiriman TBS pemasok harus membuat/menyertakan surat pengantar barang resmi yang mencantumkan No.Kontrak, tanggal panen, jumlah tandan dan asal TBS dan ditanda tangani oleh pemasok.

4. Timbangan dipakai untuk dasar pembayaran adalah timbangan pihak perusahaan.

5. Pada waktu pengiriman kepabrik, semua kendaraan pengangkut harus ditutup jaring, rantai dan disegel.

6. Pembongkaran TBS dari kendaraan angkutan dilaksanakan oleh pihak perusahaan dan biaya pembongkaran ditanggung oleh pihak perusahaan.

7. Penerimaan TBS dipabrik adalah setiap hari (24 jam). Kecuali ada trouble di PMKS pihak perusahaan maka pihak perusahaan akan memberitahukan kepada pihak pemasok.

8. Minimal tiap kali pengiriman TBS pihak pemasok kepada perusahaan adalah tidak kurang dari 1 ton $(1000 \mathrm{~kg})$

\section{Alur Penanganan Penerimaan TBS}

PT. Bio Nusantara Teknologi merupakan perusahaan yang bergerak dibidang perkebunan kelapa sawit dan memiliki pabrik pengolahan kelapa sawit. Pabrik di PT. Bio Nusantara Teknologi berkapasitas 30 ton/ jam. Jadi dalam sehari pabrik bisa mengolah \pm 720 ton/ hari dengan luas perkebunanan 4.091,41 Ha yang telah menghasilkan. PT. Bio Nusantara Teknologi bukan hanya mengolah TBS milik perusahaan saja tetapi dari pihak ketiga, yaitu dari pemasok mitra murni, pemasok mitra plasma dan dari pemasok umum.

Penerimaan TBS di PT. Bio Nusantara Teknologi Bengkulu dilakukan melalui beberapa tahap sampai menuju penyimpanan TBS. Ketiga pemasok yang menjual TBSnya harus mengikuti tahapan tersebut yang berlaku di PT.Bio Nusantara Teknologi. Penanganan penerimaan TBS antara lain: pengambilan nomor antrian (Sera I), Pemanggilan nomor antrian (Sera II), penimbangan dan bongkar muat serta sortasi dan kembali ke pos penimbangan dan pos sera II. Selain itu pemasok yang ingin menjual TBSnya ke PT. Bio Nusantara Teknologi harus memiliki DO (Delivery Order). DO merupakan nomor kontrak antara pemasok dan perusahaan.

\section{a. Sera I (Pengambilan Nomor Antrian)}

Pengambilan nomor merupakan tahap pertama bagi pemasok yang ingin menjual TBSnya ke PT. Bio Nusantara Teknologi. Pada tahapan ini pemasok yang masuk harus menyerahkan slip atau kertas yang berisi nomor DO (delivery Order), asal TBS, dan data angkutan. Slip ini bukan disediakan dari perusahaan tetapi dari masing-masing pemilik TBS yang biasanya sebagian dititipkan pada petugas. Pada tahap ini slip tersebut akan diberi nomor urut sesuai urutan pemasok yang telah masuk pada hari itu dan diberi cap yang menandakan pemasok tersebut telah siap mengikuti tahapan berikutnya. 
Petugas yang berada pada pos 1 atau pos pengambilan nomor ini merupakan seorang satpam yang terdiri dari 9 (Sembilan) petugas yang dibagi menjadi 2 orang untuk setiap shift tugasnya. Jam kerja setiap shiftnya yaitu pukul 07.00 WIB s/d 17.00 WIB dan 17.00 WIB s/d 07.00 WIB. Dilakukannya pembagian kerja berdasarkan shif karena PMKS PT.Bio Nusantara Teknologi bekerja selama 24 jam penuh tanpa henti setiap harinya. Sehingga bahan bakupun harus diterima setiap waktu pula. Adapun peran petugas pada bagian ini adalah sebagai berikut:

i. Menerima pendaftaran TBS pemilik mitra, umum dan plasma dan memberikan nomor antrian.

Pemasok yang masuk harus mendaftar agar pada saat tahapan penerimaan berikutnya berjalan tertib.

ii. Menerima laporan hasil timbangan.

Setelah pemasok masuk ke bagian penimbangan dan sortasai bongkar muat TBS, pemasok harus kembali ke sera II atau pos pemanggilan nomor antrian untuk melaporkan hasil dari timbangan dan sortasi. namun hasil dari sortasi diserahkan ke bagian sera II atau pemanggilan nomor antrian, shingga hanya hasil dari penimbangan dilaporkan kebagian pos ini.

iii. Melayani tamu yang berkunjung ke PT.Bio Nusantara Teknologi.

Pos ini juga berfungsi ganda karena merupakan pos satpam pertama setelah memasuki portal masuk di PT.Bio Nusantara Teknologi sehingga apabila ada tamu yang ingin berkunjung dapat melaporkan tujuannya ke.PT.Bio Nusantara Teknologi.

Setiap pemasok yang masuk ke PT.Bio Nusantara Teknologi saat ini setiap harinya dibatasi. Pembatasan jumlah kendaraan pemasok yang masuk berdasarkan keaktifan para pemasok menjual TBS ke perusahaan. Untuk pemasok umum jumlah pemasok yang masuk setiap harinya antara 1-14 mobil/hari. Maka jika seluruh pemasok umum yang terdaftar memasok TBS ke PT. Bio Nusantara Teknologi maka jumlah kendaraan untuk pemasok mitra saja sebanyak 45 kendaraan pemasok yang terdaftar dan aktif. Sedangkan untuk pemasok mitra dan plasma yang aktif sebanyak 37 kendaraan perhari dengan kisaran 1-13 mobil/hari. Jadi dalam sehari jumlah kendaraan yang masuk \pm 82 kendaraan/hari.

\section{b. Sera II (Pemanggilan Nomor Antrian)}

Pos untuk pemanggilan nomor antrian ini biasa disebut Sera II. Pada tahapan ini pemilik TBS atau sopir segera menyerahkan slip surat pengantar barang (DO) dipos sera II dan diisi lengkap nomor polisi, nomor 
antri, nomor antri,nomor kontrak, nama sopir, asal TBS dan pemilik kontrak. Pemasok boleh masuk ketahapan berikutnya (penimbangan dan sortasi bongkar muat) jika telah dipanggil oleh petugas dan membawa slip surat pengantar barang (DO).

Pos ini mempunyai pengaruh besar terhadap kelancaran penanganan penerimaan. Karena setelah tahapan ini pemasok akan masuk ke bagian timbangan dan sortasi yang memerlukan waktu yang cukup lama dan perlu dipantau agar tidak terjadi penumpukan kendaraan di bagian sortasi.

Selang menunggu panggilan, biasanya sopir duduk-duduk sambil mengobrol dengan sopir yang lain. Selang menunggu kendaraan yang turun dari sortasi petugas membuat laporan harian dan mengobrol dengan petugas lain. Jumlah petugas pada Sera II atau pos pemanggilan terdiri dari 9 (Sembilan) orang petugas yang juga dibagi menjadi 3 orang untuk setiap shiftnya. Shift kerja pada sera II ini sama dengan pos Sera I yaitu shift pertama pukul 07.00 WIB s/s $17.00 \mathrm{WIB}$ dengan jam istirahat pukul 12.00 WIB s/d 13.00 WIB sedangkan shift kedua yaitu pada pukul 17.00 WIB s/d 07.00 WIB dan waktu istirahat pada pukul 01.00 WIB s/d 02.00 WIB. Adapun tugas para petugas pada sera II ini antara lain:

i. Mengatur antrian mobil.

Seperti yang dijelaskan di atas, petugas selalu memantau kendaraan yang telah masuk kebagian sortasi, agar tidak terjadi penumpukan kendaraan sehingga proses penerimaan berjalan dengan lancar.

ii. Mengatur urutan mobil yang masuk ketimbangan (memanggil berdasarkan antrian).

Kendaraan yang akan masuk kebagian timbangan dipanggil berdasarkan nomor urut setiap pemasok yang telah daftar pada bagian sera I.

iii. Mencatat keluar masuknya mobil sekaligus membuat laporan untuk dilaporkan ke kantor.

Semua mobil yang masuk ke PMKS baik itu mobil pengangkut TBS, Jangkos, CPO, inti harus dicatat pada bagian ini. Tujuannya agar perusahaan tahu berapa banyak kendaraan pengangkut yang keluar masuk di PMKS. Selain itu petugas juga membuat laporan yang datanya diperoleh dari setiap pemasok yang diterima dari bagian pengambilan nomor antrian, timbangan dan sortasi.

Petugas di sera II harus terus memantau di bagian sortasi, karena jika dibagian sortasi telah kosong atau kendaraan yang masuk telah keluar maka petugas harus memanggil kendaraan antrian berikutnya. Pemasok yang masuk ke PT.Bio Nusantara Teknologi ini terdiri dari tiga kelompok 
pemasok yaitu pemasok mitra, pemasok plasma, dan pemasok umum yaitu pemasok yang tidak memiliki kerjasama dengan perusahaan. Jika keadaan sedang ramai maka pemasok harus cukup bersabar menunggu pemanggilan nomor antrian, karena untuk membongkar TBS dan sortasi TBS dari kendaraan memakan waktu \pm 20-60 menit permobil.

Pemanggilan nomor antrian kendaraan ini yang diutamakan yaitu untuk pemasok mitra, karena mitra memiliki kerjasama khusus yang memiliki standarisasi TBS yang lebih baik dari umum. Setiap harinya memang pemasok mitra yang paling banyak menjual hasil panennya ke PT. Bio Nusantara Teknologi sedangkan pemasok umum biasanya menjual TBS tergantung harga jual TBS disetiap pabrik sawit. Pemasok umum tentunya akan menjual TBSnya keperusahaan yang mematok harga tinggi untuk TBS yang dijual pemasok dan tentunya tidak merugikan pihak pemasok.

Pemanggilan antrian kendaraan ini berdasarkan prosedur operasional standard (S.O.P) mobil keluar masuk sortasi di PT. Bio Nusantara Teknologi. Mobil TBS yang masuk dalam kondisi normal adalah 3 (tiga) unit mobil besar dan 2 (dua) unit mobil kecil namun karena kondisi lapangan yang masih memungkinkan 1 (satu) kendaraan lagi masuk kesortasi maka petugas kadang memanggil hingga 6 (enam) mobil yang terdiri dari 3 (tiga) mobil besar dan 3 (tiga) mobil kecil namun yang tetap diutamakan yaitu untuk mobil mitra.

\section{c. Jembatan Timbang}

Penimbangan dilakukan dua kali untuk setiap angkutan TBS yang masuk ke pabrik, yaitu pada saat masuk (berat truk dan TBS) serta pada saat keluar (berat truk). Selisih timbangan saat truk masuk dan keluar, diperoleh barat bersih TBS yang masuk ke pabrik. Penimbangan TBS ini dilakukan untuk mengetahui realisai produksi TBS dari kebun, dan jumlah TBS yang diolah. Memasuki ketahapan sortasi pemasok harus menimbang berat kendaraan beserta TBS yang dibawa. Namun sopir harus turun sehingga ditemukan total berat keseluruhan. Alat yang digunakan untuk menimbang ini dinamakan jembatan timbang. Jembatan timbang ini berbentuk seperti jembatan yang telah ada alat yang bisa mengukur berat berton-ton. Caranya yaitu sopir pemasok TBS membawa mobilnya naik kejempatan timbang, kemudian berat mobil beserta TBS akan tercatat pada alat yang telah dipasang yang berada didalam ruangan petugas yang berada tepat disamping jembatan timbang, sehingga petugas dapat memantau kendaraan yang naik timbangan dan dengan mudah mengetahui berat kendaraan yang dibawa pemasok. Di sudut atas depan dan belakang jembatan diberi spion agar kendaraan yang menaiki jembatan timbang tepat berada ditengah sehingga penimbangann tidak salah Pada 
tahap ini hanya memerlukan waktu 2-5 menit dan kemudian kendaraan siap lanjut ke tahapan bongkat muat dan sortasi.

Tugas petugas pada tahapan ini adalah sebagai berikut:

1. Menimbang kendaraan yang masuk ataupun keluar dari pabrik baik itu kendaraan pengangkut TBS, janjang kosong, inti, cangkang, CPO ataupun hal yang berkaitan dengn pabrik dan perusahaan.

2. Membuat slip bukti penimbangan.

Bukti slip penimbangan ini dilakukan menggunakan computer. Setelah kendaraan ditimbang maka akan tercatat langsung dikomputer yang dilengkapi dengan program untuk membuat slip bukti penimbangan

3. Membuat pembukuan, hal yang dicatat dalam pembukuan ini yaitu petugas menghitung dan mencatat berat bersih TBS, janjang kosong, inti, cangkang, $\mathrm{CPO}$ yang masuk atau keluar pabrik kemudian untuk dilaporkan ke bagian kantor.

Pada tahapan ketiga ini jumlah petugas juga sama dengan jumlah petugas pada tahapan 1 (pengambilan nomor antrian) dan tahapan ke 2 (pemanggilan nomor antrian) yaitu sebanyak 9 orang, setiap shiftnya terdiri dari 2 (dua) orang petugas. Dari hasil wawancara dengan petugas, menurut mereka jumlah petugas seperti itu sudah cukup memadai untuk menangani penanganan penerimaan TBS.

\section{d. Sortasi}

TBS yang telah ditimbang selanjutnya dibongkar di loading ramp. Tahapan ini merupakan tahapan terakhir dari alur penerimaan TBS diPT.Bio Nusantara Teknologi Bengkulu. Pada tahapan ini biasanya sopir angkutan pemasok duduk didalam mobil sembari menunggu TBS yang dibawa dibongkar oleh para petugas. Petugas yang menangani bongkat muat TBS untuk setiap unit mobil yaitu sebanyak 2-3 orang petugas. Pada bagian bongkat muat jumalah petugas yaitu sebanyak 16 orang sedangkan untuk mensortasi sebanyak 27 orang. Dengan jumlah petugas sebanyak ini petugas merasa sudah sangat cukup untuk melayani tahapan bongkar muat dan sortasi dalam penangann penerimaan TBS di PT.Bio Nusantara Teknologi ini.

Sortasi dilakukan untuk mengetahui kualitas TBS dari setiap kendaraan yang masuk baik itu dari pemasok mitra, pemasok umum, ataupun pemasok plasma. Penentuan kualitas TBS dilakukan secara manual yaitu dengan cara mengambil sampel dari setiap unit kendaraan dimana sampel yang diambil untuk mobil kecil yaitu sebanyak 60 brondolan sedangkan mobil besar seperti truk diambil untuk dijadikan sampel sebanyak 120 brondolan. Tujuan dari pengambilan sampel ini adalah untuk mengetahui jenis buah TBS yang memiliki pengaruh terhadap kualitas buah. TBS yang memenuhi syarat akan diterima oleh pabrik, 
sedangkan TBS yang tidak memenuhi syarat akan ditolak. Keputusan menerima atau menolak TBS tergantung hasil pemeriksaaan kualitas. Apabila TBS diterima, maka TBS ditumpuk dibagian loading ramp yang kemudian dimasukan ke loari dan siap diolah.

Sortasi dilakukan secara transparan, dilihat langsung oleh sopir sehingga tidak terjadi kerugian atau kecurangan dari keduabelah pihak, baik itu bagi pemasok dan perusahaan. Petugas bongkar muat bertugas hanya membongkat muatan TBS yang dibawa setiap kendaraan pemasok. Sedangkan petugas sortasi memiliki tugas yang cukup banyak sehingga petugasnya pun sedikit lebih banyak dari petugas bongkar muat.

Tugas mereka antara lain sebagai berikut:

i. Melihat kualitas buah, yaitu dapat dilihat dengan cara pengambilan sampel untuk setiap kendaraan yang masuk. Untuk mobil kecil sampel TBS yang diambil sebanyak 60 brondolan TBS sedangkan mobil besar sebanyak 120 brondolan. Pada penelitian ini hanya ada 2 (dua) varietas buah sawit dari 5 (lima) varietas yang ada yaitu hanya varietas tenera dan dura. Dari pengambilan sampel inilah ditentukan persentase jenis buah tenera dan dura.

ii. Memilih kelayakan buah, baik mentah maupun masak menggunakan sistem penyeleksian.

iii. Menghitung berat rata-rata buah yang dapat menentukan harga TBS yang dibagi menjadi 3 (tiga) kelas yaitu kelas A berat rata-rata buah $>12 \mathrm{~kg} /$ tandan, kelas B berat rata-rata buah antara 7-12 kg/tandan sedangkan kelas $C$ berat rata-rata buah antara $5-7 \mathrm{~kg} /$ tandan.

iv. Menangani masalah potongan TBS apabila ada campuran yang disengaja maupun tidak disengaja baik itu berupa pasir, sampah dan lainnya selain TBS yang baik yang akan dibawa pulang oleh pemasok.

Kriteria buah yang dipulangkan yaitu: (a) Fraksi 00 (mentah), (b) Fraksi 0 (mentah 1), (c) Komidel 2 (dibawah 4 kg/tandan), (d) Berupa janjangan kosong (Jangkos), dan (e) Buah yang restan $>72$ jam

Waktu yang dibutuhkan untuk melakukan bongkat muat TBS ini cukup lama dan berbeda-beda antara mobil besar dan mobil kecil. Pebedaan ini disebabkan karena kapasitas mobil yang berbeda-beda. Untuk pemasok umum yang rata-rata kendaraan yang dibawa adalah mobil kecil makan rata-rata waktu yang dibutuhkan dalam sortasi yaitu selama 39 menit 63 detik / unit kendaraan dengan kisaran waktu antara 8 menit 4 detik - 1 jam 28 menit 8 detik/unit kendaraan. Untuk pemasok mitra rata-rata waktu yang dibutuhkan dalam tahapan ini yaitu 49 menit 15 detik/unit kedaraan dengan kisaran waktu bngkat antara 9 menit - 1 jam 57 menit/unit kendaraan. Sedangkan waktu yang dibutuhkan untuk pemasok 
plasma yaitu berkisar antara 18 menit - 1 jam 48 menit 2 detik/unit kendaraan dan rata-rata waktu bongkar selama 54 menit/ unit kendaraan.

Perbedaan waktu penanganan ini bukan hanya disebabkan jumlah muatan di dalam kendaraan tetapi juga ada yang disebabkan oleh kendalakendala teknis seperti terlalu banyak pemasok yang mengantri untuk menjual hasil TBS, loari dalam keadaan penuh ini mengakibatkan kendaraan yang telah masuk kebagian sortasi harus menunggu sedangkan waktu telah dihitung, mesin pabrik tiba-tiba macet atau rusak sehingga kendaraan yang masuk harus menunggu disortasi sedangkan waktu telah dihitung setelah kendaraan mulai masuk kebagian bongkar muat, namun pada keadaan pabrik sedang sepi proses bongkar muat akan berjalan dengan lancar dan cepat.

Setelah melewati tahapan sortasi, kendaraan pemasok TBS harus kembali ke jembatan timbang untuk menghitung berat kendaraan kosong yang nantinya berfungsi untuk menghitung berat bersih TBS yang masuk kepabrik di PT. Bio Nusantara Teknologi dan berfungsi untuk menentukan total dana yang harus dibayar ke setiap pemasok. Selain itu pemasok harus tetap melaporkan hasil dari sortasi dan penimbangan ke sera II, sebagai pemberitahuan bahwa kendaraan pengangkut TBS yang pemasok bawa telah selesai melakukan penanganan penerimaan TBS di PT.Bio Nusantara Teknologi.

\section{Harga TBS Pemasok Umum, Mitra Dan Plasma}

Harga TBS ditetapkan berdasarkan harga CPO dan inti. Jika harga CPO tinggi maka harga TBS juga ikut tinggi dan sebaliknya, jika harga CPO relatif rendah maka harga TBS pun rendah hal ini sesuai dengan hukum ekonomi. Perubahan harga TBS di PT.Bio Nusantara Teknologi diberitahu pada hari Senen dan hari Kamis. Penentuan harga TBS diberitahukan kepada pemasok melalui papan pengumuman di kantor satpam Pabrik Minyak Kelapa Sawit (PMKS) perusahaan pada pagi hari berlaku mulai pukul 07.00 WIB. Kualitas TBS mempengaruhi harga yang diterima oleh setiap pemasok. Kualiatas TBS meliputi persetase buah tenera dan dura, tingkat kematangan buah (persentase brondol) dan restan buah, namun yang sangat mempengaruhi yaitu persentase tenera dan dura dan restan buah. Penilaian harga tersebut berdasarkan 3 (tiga) kelas, yaitu :

1) Kelas A : berat buah rata-rata $>12 \mathrm{~kg} / \operatorname{tandan}$

2) Kelas $B$ : berat buah rata-rata $8-12 \mathrm{~kg} /$ tandan

3) Kelas $\mathrm{C}$ : berat buah rata-rata $4-8 \mathrm{~kg} / \operatorname{tandan}$

Perbedaan harga untuk setiap kelasnya yaitu sebanyak Rp. 25,00/ kg, walaupun perbedaannya sangat kecil namun memberikan pengaruh yang cukup besar karena pemasok dalam sehari menjual TBS ke PT. Bio Nusantara Teknologi minimal 3-4 ton. 
Restan buah mempengaruhi pengurangan berat TBS bahkan TBS dapat ditolak. Restan merupakan waktu dari pemanenan hingga TBS dibawa ke pabrik. Ada 3 karakter restan di PT. Bio Nusantara Teknologi yaitu:

1) $48-60$ jam potongan $4 \%$ total berat

2) $>60-72$ jam potongan $8 \%$ total berat

3) > 72 potongan $100 \%$ total berat atau ditolak

Pemberian harga untuk pemasok mitra ataupun plasma disesuaikan oleh persentase tenera pemasok. Persentse buah tenera pemasok mitra dan plasma yaitu $\geq 60 \%$. Perbedaan harga antara persentase tenera $60 \%-75 \%$ dan $>75 \%$ yaitu sebesar Rp. 15,- dan selisih Rp.60 sampai Rp.75 dari harga dasar yang biasa diberikan oleh pemasok umum. Lain halnya dengan pemasok umum, mereka hanya diberi harga sesuai harga yang telah ditetapkan oleh perusahaan, karena pada umumnya pemasok umum persentase tenera sangat kecil atau kurang dari $60 \%$ dan akan menghasilkan rendemen yang rendah.

Harga TBS terendah untuk pemasok umum pada bulan Juli 2011 yaitu Rp.1.200 dan harga tertinggi untuk pemasok umum yaitu Rp.1.325, sedangkan harga untuk pemasok mitra dan plasma memiliki harga yang sama yang dilihat berdasarkan persentase tenera setiap buah. Untuk persentase tenera $>75 \%$ harga terendah untuk bulan Juli 2011 yaitu Rp.1.275 sedangkan harga tertinggi yaitu Rp.1.400. namun jika persentase buah tenera antara $60-75 \%$ maka harga terendah untuk bulan Juli 2011 yaitu Rp.1.260 dan harga tertinggi Rp.1.385. namun jika persentase buah tenera dibawah 60\% maka harga akan dipotong sebesar persentase teneranya (Lampiran 9). Harga tinggi yang ditetapkan inilah yang menjadi salah satu keuntungan menjadi mitra di PT.Bio Nusantara Teknologi.

\section{Pembayaran TBS}

Setelah mengikuti tahapan penerimaan TBS, pemasok dapat pemperoleh pembayaran dari hasil jual TBS. pembayaran TBS dilakukan setiap hari kerja dari pukul 08.00 WIB sampai jam 14.00 WIB, kecuali pada hari sabtu yaitu hanya sampai pukul 11.00 WIB. Namun jika TBS yang masuk di luar jadwal waktu pembayaran, maka akan dibayar pada hari kerja berikutnya. Pembayaran dilakukan secara tunai namun dapat pula dilakukan melalui transfer kerekening bank yang telah ditunjuk oleh pihak kedua / pemasok dengan memberikan surat kuasa kepada pihak perusahaan. TBS yang dibayar perusahaan merupakan TBS yang diterima setelah ada persetujuan dari sortasi dan timbangan Pabrik Minyak Kelapa Sawit (PMKS) dan telah ditandatangani oleh bagian pengadaan TBS.

\section{Analisis Beda Nyata Jujur (BNJ)}

Menurut Furqon (2008) Uji BNJ merupakan uji lanjutan dari uji ANAVA. Maka dari itu perlu dilakukan terlebih dahulu uji ANAVA. Pusat perhatian 
ANAVA adalah pada kelompok dengan variasi yang bersumber dari perbedaan subjek di dalam kelompok.

Tabel 4. Analisa Varian

\begin{tabular}{lcccccc}
\hline $\begin{array}{c}\text { Sumber } \\
\text { Keragaman }\end{array}$ & $\begin{array}{c}\text { Derajat } \\
\text { Bebas (Db) }\end{array}$ & Jumlah & Kuadrat (JK) & Tengah (KT) & F & \multicolumn{2}{c}{ F table } \\
hitung & $\mathbf{5 \%}$ & $\mathbf{1 \%}$ \\
Pemasok & 2 & $177.899,3$ & 88949,65 & $341,10^{* *}$ & 3,06 & 4,75 \\
Galat & 144 & 491.000 & 3409,72 & - & & \\
Total & 146 & $668.899,3$ & - & - & & \\
\hline
\end{tabular}

Keterangan: $\left.{ }^{* *}\right)=$ sangat nyata

$\mathrm{KK}=\sqrt{ }($ KT galat $) / \mathrm{y}^{-} \times 100 \%=1.51 \%$

Hasil uji $\mathrm{F}$ ini menunjukan derajat pengaruh pemasok terhadap data hasil percobaan. Dari hasil analisis varian (Tabel 4) diperoleh bahwa ragam pemasok berpengaruh sangat nyata terhadap harga yang diperoleh karena nilai $\mathrm{F}_{\text {hitung }}$ 341,10 > F 1\% 4,75. Karena nilai KK (koefisien Keragaman) yang menunjukan derajat kejituan kecil yaitu $<5 \%$ maka dilakukan uji lanjutan dengan uji BNJ.

Derajat bebas pemasok diperoleh dari jumlah pemasok yaitu 3 (tiga) dikurang 1 (satu) maka diperoleh nilai derajat bebas pemasok yaitu 2 (dua). Nilai 1 (satu) merupakan rumus dari penentuan derajat bebas.

Tabel 5. Hasil Uji Beda Rata-Rata Harga Antara Pemasok Umum, Mitra Dan Plasma

\begin{tabular}{|c|c|}
\hline Pemasok & Rata-Rata \\
\hline Umum & $1.237,76 \mathrm{a}$ \\
\hline Mitra & $1.305,92 b$ \\
\hline Plasma & $1.316,12 c$ \\
\hline
\end{tabular}

BNJ 1\% 34,3

Keterangan : Huruf (superscript) yang berbeda dalam kolom yang sama menunjukkan berbeda nyata $(P<0.01)$ berdasarkan uji beda nyata jujur HSD

Hasil analisis ragam dan uji beda nyata jujur 1\% (Tabel 5) dengan nilai kritis BNJ 34,3 menunjukkan bahwa terdapat perbedaan yang nyata pada harga disetiap pemasok yaitu pemasok umum, mitra dan plasma. Hal ini ditunjukan pada tanda huruf a,b dan c. Pasangan yang berpengaruh beda nyata atau pengaruh beda sangat nyata beri tanda huruf yang tidak sama. Pemberian tanda huruf ini dilakukan sesuai prosedur dan terlebih dahulu perlakuan diurutkan sesuai dengan urutan minimal ke maksimal yaitu umum (minimal) ke plasma (maksimal). Kemudian dijumlah antara nilai kritis $\mathrm{BNJ} 1 \%=34,3$ dengan nilai rata-rata perlakuan terkecil pertama, yaitu $1.237,76+34,3$ $=1.272,06$ dan diberi huruf " $a$ " dari nilai rata-rata perlakuan terkecil pertama 
$(1.237,76)$ hingga nilai rata-rata perlakuan berikutnya $\leq$ nilai $1.272,06$, dalam penelitian ini huruf "a" hanya pada perlakuan pemasok umum saja.

Selanjutnya dijumlahkan nilai kritis $\mathrm{BNJ} 1 \%=34,3$ dengan nilai rata-rata perlakuan terkecil kedua, yaitu 1.305,92 $+34,3=1.340,22$ dan diberi huruf " $b$ " dari nilai rata-rata perlakuan terkecil kedua $(1.305,92)$ hingga nilai rata-rata perlakuanberikutnya yang $\leq$ nilai $1.340,22$. Dalam penelitian ini yang memiliki nilai antara 1.305,92-1.340,22 hanya pada perlakuan pemasok mitra.

Langkah selanjutnya dijumlahkan nilai kritis $\mathrm{BNJ} 1 \%=34,3$ dengan nilai rata-rata perlakuan terkecil ketiga, yaitu $1.316,12+34,3=1.350,42$ dan berihuruf " $c$ " dari nilai rata-rata perlakuan terkecil kelima $(1.316,12)$ hingga nilai rata-rata perlakuan berikutnya yang $\leq$ nilai 1.350,42. Dalam penelitian ini yang memiliki nilai antara 1.316,12-1.350,42 hanya pada perlakuan pemasok plasma. Jadi antara ketiga pemasok memiliki huruf yang berbeda, ini artinya harga TBS antara pemasok umum, pemasok mitra dan pemasok plasma berbeda nyata.

Rata-rata harga tertinggi yaitu pada pemasok plasma yaitu Rp 1,316.12. Perbedaan rata-rata setiap pasangan adalah sebagai berikut:

$\begin{array}{lll}\text { C1 (Plasma vs umum) } & =1.316,12-1.237,76 & =78,37 \\ \text { C2 (Plasma vs mitra) } & =1.316,12-1.305,92 & =10,20 \\ \text { C3 (Mitra vs umum) } & =1.305,92-1.237,76 & =68,16\end{array}$

Namun selisih yang paling besar yaitu antara plasma dan umum yaitu Rp. 78,37, sedangkan selisih plasma dan mitra hanya Rp. 10,20. Selisih antara mitra dan umum yaitu Rp. 68,16 tidak berbeda jauh dengan selisih antara plasma dan umum. Jadi dapat diartikan secara umum bahwa harga untuk pemasok umum sangat jauh dibawah harga pemasok mitra dan pemasok plasma. Harga pemasok mitra dan pemasok umum dengan rata- rata yang tidak berbeda jauh. Dengan kata lain, dengan ketentuan bahwa kualitas mempengaruhi harga maka terbukti bahwa kualitas persentase tenera pada pemasok mitra dan plasma lebih baik dibandingkan dengan kualitas persentase tenera pada pemasok umum. Sehingga dengan adanya pasokan TBS dari mitra dan umum dapat membantu memperbaiki kualitas TBS yang diperoleh dari pemasok umum setelah diolah nanti.

Hasil tersebut menunjukan ketiga nilai antara rata-rata setiap pasangan lebih besar daripada nilai kritis HSD. Dengan kata lain, uji tukey menghasilkan tiga nilai yang signifikan pada $p<0,01$

Harga dipengaruhi oleh persentse tenera dan kelas buah atau kualitas buah, pada pemasok umum bibit tidak mengikuti standarisasi perusahaan maka dari itu harga yang ditetapkanpun rendah dari pemasok mitra dan plasma yang memiliki selisih yang cukup besar. Pada dasarnya penetapan harga TBS pemasok mitra dan pemasok plasma sama namun dalam terkadang persentase tenera yang dihasilkan dari TBS mitra dan plasma tidak selalu sama. Hal inilah yang menyebabkan perbedaan atau selisih rata-rata antara 
keduanya. Namun bibit pemasok mitra dan plasma telah sesuai standarisasi perusahaan yaitu dengan persentase tenera $>60 \%$.

\section{Klasifikasi Pemasok Berdasarkan Penanganan Penerimaan TBS}

Ada 5 (lima) poin yang berkaitan dengan penanganan penerimaan tandan buah segar khususnya penanganan di bagian sortasi di PT.Bio Nusantara Teknologi, yaitu berat TBS, berat brondol (tingkat kematangan), persentasi tenera dan dura, waktu sortasi, harga TBS. Kelima poin ini berpengaruh dan diketahui pada saat sortasi.

\section{a. Berat/Pasokan TBS}

Berat TBS diketahui pada saat penimbangan di jembatan timbang. Penimbangan ini dilakukan dua kali yaitu pada saat masuk dan pada saat keluar atau setelah dilakukan sortasi dan bongkar muat. Penimbangan berat TBS pada saat masuk yang dapat dihitung hanyalah berat kotor atau sebelum sortasi. Maka dari itu sortasi berpengaruh terhadap berat TBS bersih yang dibutuhkan untuk menghitung harga yang harus dibayar perusahaan kepada pemasok nantinya.

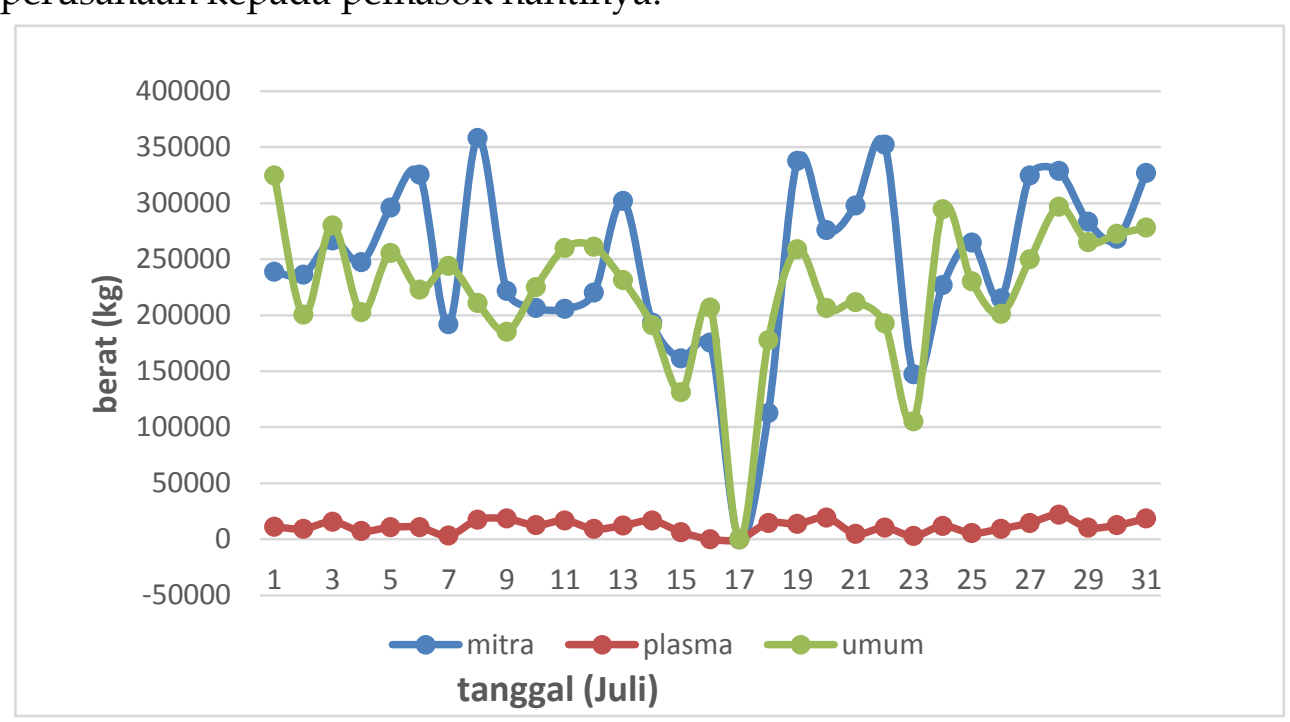

Gambar 2.

Grafik Jumlah Pasokan TBS Bulan Juli 2011

Menurut gambar 2 di atas fluktuasi pasokan naik turun. Jumlah pasokan tertinggi sebesar $358.010 \mathrm{~kg}$ yaitu pada tanggal 08 Juli 2011 oleh pemasok mitra, dan jumlah pasokan terendah sebesar $0 \mathrm{~kg}$ pada tanggal 16 Juli 2011 oleh pemasok plasma karena pada hari itu pemasok plasma sedang tidak ada produksi. Tanggal 17 Juli 2011 pabrik sedang dalam perbaikan sehingga pabrik tidak menerima pasokan dari pemasok 
luar.Dari grafik diatas sangat terlihat jelas perbedaan pasokan antara pemasok umum, mitra dan plasma. Pasokan pemasok plasma cendrung datar dan sangat rendah yaitu kurang dari $50.000 \mathrm{~kg} / \mathrm{hari}$, namun walaupun jumlah pasokan TBS sedikit, pemasok plasma harus tetap memasok TBS ke PT. Bio Nusantara Teknologi karena telah sesuai kesepakatan di dalam kontrak oleh kedua belahpihak. Pasokan yang sedikit ini disebabkan karena jumlah lahan yang dimiliki pemsok plasma sangat jauh berbeda dibanding dengan pemasok mitra sehingga jumlah TBS yang dihasilkan juga rendah. Pemasok umum merupakan pemasok yang memiliki jumlah pasokan terbanyak kedua setelah pemasok mitra, dengan pasokan tertinggi sebesar $324.490 \mathrm{~kg}$ dan pasokan terendah sebesar $105.330 \mathrm{~kg}$.

Berikut merupakan berat TBS dan berat brondol untuk setiap pemasok yaitu pemasok umum, mitra, dan plasma:

Tabel 6. Berat Rata-Rata Perhari TBS Setiap Pemasok Pada Bulan Juli $2011(\mathrm{~kg})$

\begin{tabular}{|c|c|c|c|}
\hline No & Pemasok & Netto TBS & Brondol \\
\hline 1. & Umum & 6.871 .670 & $11.679,22$ \\
\hline 2. & Mitra & 7.605 .640 & $32.298,75$ \\
\hline 3. & Plasma & 347.220 & 834,58 \\
\hline 4. & Perkebunan inti & 3.297 .490 & \\
\hline & Rata-rata & $584.581,29$ & \\
\hline
\end{tabular}

Keterangan: data sekunder yang diolah

Total pasokan TBS selama satu bulan yaitu sebesar $18.122 .020 \mathrm{~kg}$, dengan rata-rata perhari $584.581,29 \mathrm{~kg}$. Jika dilihat dari rata-rata pasokan TBS pemasok umum yaitu sebesar $221.666,77 \mathrm{~kg}$ ini dapat menutupi kekurangan bahan baku yang dibutuhkan perusahaan dengan tambahan total rata-rata pemasok mitra, plasma dan perkebunan inti dengan sebesar 362.914,52 kg (Lampiran 4). Kapasitas terpasang mesin pengolahan yaitu sebesar $30 \mathrm{ton} / \mathrm{jam}$ untuk meproduksi CPO, namun dari informasi yang diterima dalam sehari mesin dapat beroperasi sebanyak \pm 20 kali pengolahan TBS.

\section{b. Berat Brondol (tingkat kematangan buah)}

Brondol adalah istilah untuk butir-butir buah sawit merahyang terlepas dari tandan ketikabuah kelapa sawit dipetik. Brondol yang lepas 
dari tandan menggambarkan seberapa baik TBS yang dipetik. "Baik" dalam hal ini yaitu mengenai buah mentah, matang sempurna, kematangan ataupun buah busuk.

Dilihat dari tabel 6 di atas jika dibandingkan dengan rata-rata jumlah pasokan setiap pemasok, untuk pemasok umum persentase brondol hanya sebesar $5,27 \%$, untuk pemasok mitra sebesar $13,16 \%$ dan pemasok plasma $7,45 \%$. Ini artinya bahwa pemasok umum dan plasma memiliki fraksi TBS yang kurang baik karena memiliki jumlah brondol lepas $<12,5 \%$ sehingga hanya dapat menghasilkan rendemen minyak yang rendah dan kadar ALB juga tinggi. Sedangkan untuk pemasok mitra memiliki persentase brondolan yang lepas sebesar 13,16 \% dimana memiliki tingkat kematangan TBS yang baik yaitu melebihi $12,5 \%$.

\section{c. Persentase tenera dan dura}

Varietas buah yang terdapat di PT. Bio Nusantara Teknologi hanya jenis tenera dan dura sedangkan ketiga varietas lain tidak ada, karena kedua jenis buah ini pada umumnya ditanam di perkebunan rakyat. Jenis buah tenera adalah jenis buah sawit yang dianggap unggul karena dapat menutupi kekurangan dari jenis buah lainnya seperti dura dan pisifera yang merupakan indukan dari jenis buah tenera ini. Jenis buah tenera memiliki daging buah yang tebal dan cangkang yang kecil sehingga dapat menghasilkan minyak lebih banyak dibandingkan jenis buah lainnya. Seperti yang telah dijelaskan pada subbab sebelumnya, jenis buah yang diterima di PT.Bio Nusantara Teknologi yaitu jenis buah tenera dan dura. di PT.Bio Nusantara Teknologi, jenis buah tenera biasanya bnyak dimiliki pemasok mitra dan plasma karena kedua pemasok ini memliki bibit yang telah menjadi standarisasi perusahaan.

Tabel 7. Rata-rata Persentase Tenera dan Dura Setiap Pemasok Bulan Juli 2011

\begin{tabular}{cccc}
\hline \multirow{2}{*}{ No. } & \multirow{2}{*}{ Jenis pemasok } & \multicolumn{2}{c}{ Kualitas Buah } \\
\cline { 3 - 4 } & & \% tenera & \% dura \\
\hline 1. & Plasma & 77,12 & 22,878 \\
2. & Mitra & 76,42 & 23,58 \\
3. & Umum & 23,04 & 76,95 \\
\hline
\end{tabular}

Sumber: data sekunder yang diolah

Telah dijelaskan pada bab sebelumnya, pemasok umum merupakan pemasok yang berasal dari berbagai daerah tanpa ada batasan, namun persentase tenera pemasok umum jauh lebih rendah dari TBS yang berasal dari pemasok mitra dan plasma. Sehingga TBS yang berasal dari pemasok 
mitra dan plasma berfungsi untuk menutup kekurangan TBS dari pemasok umum yaitu terutama mengenai kualitas yang berkaitan dengan persentase tenera dan dura.

Lebih jelasnya mengenai tabel di atas dapat dilihat pada lampiran 6 . Dari tabel di atas, urutan persentase tenera terbesar yaitu pemasok plasma, pemasok mitra kemudian pemasok umum. Namun persentase tenera untuk pemasok mitra dan plasma tidak begitu jauh karena bibit telah sesuai dengan standarisasi perusahaan yang telah diatur berdasarkan kontrak kerjasama antara mitra dan perusahaan.

\section{d. Waktu sortasi}

Penghitungan waktu sortasi dikerjakan oleh petugas pada bagian sera II (pos pemanggilan nomor antrian) dengan cara mencatat jam masuk ke sortasi dan jam keluar dari sortasi kemudian diestimasikan sehingga didapat waktu sortasi setiap kendaraan yang masuk.

Tabel 8. Waktu sortasi setiap kendaraan yang masuk

\begin{tabular}{ccc}
\hline No & pemasok & waktu rata-rata (detik $/ \mathrm{kg})$ \\
\hline 1 & mitra & 0,68 \\
2 & plasma & 0,76 \\
3 & umum & 1,13 \\
\hline rata-rata & & 0.85 \\
\hline
\end{tabular}

\section{Sumber: data sekunder yang diolah}

Dari tabel di atas, untuk melakukan sortasi petugas lebih cepat melakukan sortasi pada pemasok mitra dan paling lama pada pemasok umum (Lampiran 8). Waktu yang cukup lama ini dapat diasumsikan bahwa ada beberapa kendala yang dihadapi, bisa saja berupa banyaknya sampah, buah mentah, janjangan kosong, sehingga diperlukan waktu yang cukup lama dalam proses sortasi. Waktu sortasi yang cepat, dapat mempercepat TBS yang masuk untuk diolah dari setiap pemasok sehingga dapat mengantisipasi kerusakan pada TBS seperti restan buah yang akan mempengaruhi kualitas dari hasil pengolahan TBS.

Menurut Noor Hidayat (1998) TBS yang tidak segera diolah, maka kandungan ALB-nya semakin meningkat. Untuk menghindari hal tersebut, maksimal delapan jam setelah dipanen, TBS harus segera diolah, kebalikan dari pembentukan minyak adalah penguraian atau hidrolisis lemak menjadi gliserol dan asam lemak bebas. Maka dari itu perusahaan membatasi waktu restan maksimal 72 jam, dan ada potongan berat yang akan mempengaruhi total harga pembelian. Jika restan lebih dari 72 jam maka TBS dari pemasok akan ditolak. Namun dalam penelitian ini tidak 
ditemukan restan TBS yang lebih dari 72 jam, sehingga buah masih layak diolah.

\section{Harga TBS}

Harga TBS adalah nilai rupiah yang harus dibayar perusahaan terhadap hasil jual TBS setiap pemasok. Harga TBS dapat berubah-ubah sesuai dengan harga CPO dunia. Harga TBS untuk setiap pemasokpun berbeda-beda tergantung pada persentase tenera dan dura TBS yang dibawa pemasok.

Harga antara pemasok mitra dan pemasok plasma harga yang akan diterima oleh pemasok sama, tetapi dilihat juga bagaimana kategori kualitas tenera yang dibawa oleh setiap pemasok, yaitu persentase tenera $75 \%$ dan persentase tenera $60 \%-75 \%$. Namun sangat terlihat perbedaan harga yang cukup jauh antara pemasok mitra dan plasma dengan pemasok umum. Harga TBS untuk pemasok umum tidak dikategorikan berdasarkan persentase tenera dan dura karena secara umum kualitas tenera untuk pemasok umum sangat kecil di bawah $60 \%$ sehingga harganya pun rendah.

Harga tertinggi yang diterima pemasok mitra dan plasma yaitu mencapai harga Rp.1.400,- / kg sedangkan harga tertinggi untuk pemasok umum hanya Rp.1.325,/kg. untuk harga terendah yang diterima pemasok mitra dan plasma yaitu Rp.1260,-/kg dan untuk pemasok umum Rp.1.200,-/kg. Adanya perbedaan harga tersebut didasari oleh persentase tenera dan restan buah yang dibawa pemasok yang dilihat pada saat sortasi dan disaksikan oleh pembawa TBS, sehingga pembawa TBS juga mengetahui persentasse tenera yang dibawa dan harga yang nantinya kan diterima.

Jika dikaitkan dengan poin sebelumnya, ternyata harga sangat berpengaruh terhadap kualitas TBS. Semakin baik TBS yang di bawah maka semakin tinggi harga yang diterima oleh pemasok.

\section{Peluang Perbaikan Oleh PT. Bio Nusantara Teknologi}

Dari kelima poin klasifikasi yang telah dijelaskan di atas, dapat disarankan beberapa peluang perbaikan yang dapat dilakukan oleh PT. Bio Nusantara Teknologi antara lain sebagai berikut :

1. Peluang perbaikan yang dapat dilakukan perusahaan terhadap pemasok mitra dan plasma yang memiliki persentase buah tenera yang baik yaitu di atas $60 \%$ sedangkan jumlah pasokan masih sedikit dibandingkan dengan pemasok umum maka dapat dilakukan perekrutan lebih banyak pemasok mitra dengan standarisasi perusahaan dan penambahan petani plasma sehingga meningkatkan luas lahan dan dapat meningkatkan produksi TBS sehingga dapat menyeimbangi kualitas buah dai pemasok umum yang memiliki persentase tenera yang sangat kecil atau $>60 \%$. 
2. Lamanya waktu sortasi dapat disebabkan karena pemilihan produk selain TBS seperti sampah. Peluang perbaikan yang dapat dilakukan PT. Bio Nusantara Teknologi yaitu dengan cara memberi sanksi berupa denda bagi pemasok yang membawa produk selain TBS untuk member efek jera kepada pemasok, sehingga proses sortasi dapat lebih cepat.

3. Agar penetapan persentasi tenera atau kualitas TBS lebih objektif, perbaikan yang dapat dilakukan perusahaan yaitu membuat sistem sortasi untuk mengetahui kualitas TBS dengan menggunakan alat analisis kualitas yang lebih objektif, tidak secara manual yang dilakukan sekarang.

4. Peluang perbaikan untuk mengatasi persentase brondol yang menggambarkan tingkat kematangan buah, perusahaan dapat lebih proaktif untuk mensosialisasikan kepada stakeholder mengenai hal teknis budidaya, waktu panen dan pasca panen kelapa sawit. Khususnya untuk pemasok plasma, perusahaan membuat sistem pengontrolan yang instensif untuk memperbaiki tingkat kematangan TBS yang dibawa pemasok.

5. Perusahaan dapat membuat koperasi yang menyediakan bibit yang tersertifikasi untuk memperbaiki kualitas buah, karena bibit yang unggul salah satu hal yang sangat mempengaruhi kualitas buah.

\section{SIMPULAN DAN SARAN}

\section{Simpulan}

Dari penelitian yang telah dilakukan penulis yang berjudul Analisis Penanganan Penerimaan Tandan Buah Segar (TBS) Pada PT.Bio Nusantara Teknologi di Kecamatan Pondok Kelapa Kabupaten Bengkulu Tengah, maka dapat disimpulkan bahwa:

1. Sistem penanganan penerimaan tandan buah segar (TBS) yang dilakukan oleh PT.Bio Nusantara Teknologi terdiri dari beberapa tahapan yaitu (a) Pengambilan nomor antrian, (b) Pemanggilan nomor antrian, (c) Penimbangan, dan (d) Sortasi dan bongkar muat

2. Terdapat perbedaan yang nyata antara harga pemasok umum,pemasok mitra dan pemasok plasma dengan perbandingan selisih harga TBS antara harga pemasok plasma dan umum sebesar Rp. 78,37/ kg, antara pemasok plasma dan mitra sebesar Rp. 10,20/kg dan selisih antara pemasok mitra dan umum sebesar Rp.68,16/kg.

3. Peluang perbaikan penanganan penerimaan TBS yang dapat dilakukan oleh PT. Bio Nusantara Teknologi adalah sebagai berikut:

a. Dilakukan perekrutan lebih banyak pemasok mitra dan penambahan petani plasma sehingga meningkatkan luas lahan

b. memberi sanksi berupa denda bagi pemasok yang membawa produk selain TBS. 
c. membuat sistem sortasi untuk mengetahui kualitas TBS dengan menggunakan alat analisis kualitas yang lebih objektif.

d. Mensosialisasikan kepada stakeholder mengenai hal teknis budidaya, waktu panen dan pasca panen kelapa sawit.

e. Membuat koperasi yang menyediakan bibit yang tersertifikasi untuk memperbaiki kualitas buah.

\section{Saran}

Berdasarkan hasil penelitian, maka penulis memberikan saran sebagai bahan masukan bagi perusahaan, pemasok atau masyarakat petani sawit dan pemerintah. Adapun saran tersebut antara lain:

a. Bagi Perusahaan

i. Sebaiknya perusahaan lebih banyak merekrut mitra dan petani plasma untuk menutupi kualitas buah yang kurang baik dari pemasok umum karena pemasok mitra memiliki kualitas TBS yang baik dibanding pemasok lainnya.

ii. Sebaiknya perusahaan melakukan kontrol yang lebih baik lagi pada pemasok plasma, agar pemasok dapat secara rutin memasok buah ke perusahaan. Karena sangat disayangkan kualitas buah cukup baik namun jumlah pasokan buah yang masuk sangat sedikit disbanding dengan pemasok mitra dan umum.

b. Bagi Pemasok/Masyarakat Petani Sawit

Bagi pemasok umum sebaiknya meningkatkan lagi kualitas TBS yang akan dijual ke PMKS, baik itu dengan cara menggunakan bibit yang bersertifikat dan juga pemeliharaan yang baik pula agar harga jual yang didapat lebih tinggi.

c. Bagi Pemerintah

Bagi pemerintah daerah sebaiknya dapat menyediakan, memperbaiki, mensosialisaikan mengenai bibit sawit yang bersertifikat dan berkualitas baik, sehingga para petani sawit dapat memahami keuntungan dari penggunaan bibit sawit yang baik dan kualitas sawit di Bengkulu meningkat. 


\section{DAFTAR PUSTAKA}

Anonim. 2011. Kelapa Sawit. Diunduh dari http://id.wikipedia.org/wiki/Kelapa_sawit, 13 april 2011

Anonim. 2011. Kajian Pasar dan Peluang Kelapa Sawit. Diunduh dari http://regionalinvestment.bkpm.go.id/newsipid/userfiles/komoditi/ 2/oilpalm_kajianpeluanginvestasi.pdf. 17 februari 2012

Arianto, E. 2008. Perilaku Harga Minyak Sawit. http://www.google.com. 12 oktober 2011

Bangun. 1989. Pemasaran Tandan Buah Segar Kelapa Sawit di Indonesia. Seminar Sehari 16 Nopember 1989. Editorial : Hutabarat, M.S., dkk. Penerbit USU. Medan.

Djohar, dkk. 2004. Membangun Keunggulan Kompetitif CPO Melaui Supply Chain Management: Studi Kasus di PT. Eka Dura Indonesia, Astra Agro lestari, Riau, Jurnal Manajemen dan Agribisnis, vol. 1 no. 1 Maret $2004: 20-23$

Effendi, zulhan. 2007. Stasiun Penerimaan buah di Pabrik Kelapa Sawit. http:// panduankelapasawit.blogspot.com/2007/11/stasiunpenerimaan-buah-di-pabrik.html. 18 mei 2011

Furqon. 2008. Metodologi penelitian. Diunduh dari http://repository.upi.edu/operator/upload/s_b0351_050099_chapter3. pdf, 17 Desember 2012

Hanafiah KA. 1993. Rancangan Percobaan, Teori, Dan Aplikasi . edisi Revisi. Raja Garfindo persada, Jakarta

La Midjan, 2001, "Sistem Informasi Akuntansi Pendekatan Manual Praktika Penyusunan Metode dan Prosedur - Edisi Kesepuluh", Bandung : Lembaga Informatika Akuntansi.

Naibaho, P.M. 1996. Tekhnologi pengolahan Kelap Sawit. Pusat Penelitian Kelapa Sawit, Medan

Hidayat, Noor. 1998. Pembahasan Pabrik Kelapa Sawit. http://www.scribd.com/doc/39034568/Bagian-Pembahasan-PabrikKelapa-Sawit, 14 november 2011

Pahan , I. 2007. Panduan Lengkap Kelapa Sawit: Manajemen Agribisnis Dari Hulu hinggga Hilir. Cetakan kedua. Penebar Swadya, Jakarta

Priyono, herry. 2008. Budidaya Tanaman Kelapa sawit. http:/ / btsmkn2tgt.blogspot.com. 18 mei 2011

Riwahyuni.2000. Peranan Pengendalian Intern Pembelian Bahan Baku Dalam Menunjang Kelancaran Proses Produksi (Studi Kasus Pada PT."G" di Bandung). Universitas widiatama. (tidak di publikasikan) 
ISSN: 1412-8837

Susanto, Harry. 2011. Jurnal : Penetapan Harga Tandan Buah Segar Kelapa Sawit di Sumatera Selatan dari Perspektif Pasar Monopoli Bilateral. http://indonagro.blogspot.com/2011/02/jurnal-penetapan-hargatandan-buah.html . 27 november 2011

Tabah, fiqih. 2011. Pabrik Minyak Kelapa Sawit. http://lemmod.blogspot.com/2011/01/pabrik-minyak-kelapa-sawiti.html. 18 mei 2011

Wigena, dkk. 2009. Desain Model Pengelolaan Kebun Kelapa Sawit Plasma Berkelanjtan Berbasis Pendekatan Sistem Dinamis (Studi Kasus: Kebun Kelapa Sawit Plasma PTP Nusantara V Sei Pagar, Kabupaten Kampar, Propinsi Riau), Jurnal Agro ekonomi, Volume 27 No.1, mei 2009 : 81- 108

Wahyono, T. dkk. 1996. Profil Kelapa Sawit Di Indonesia. Pusat Penelitian Kelapa Sawit, Medan.

Wikipedia. 2011. Penghargaan. http://id.wikipedia.org/wiki/Penghargaan, 14 november 2011

Yan Fauzi, Y. E. dkk. 2002. Kelapa Sawit: Budidaya, Pemanfaatan Hasil dan Limbah , Analisis Usaha dan Pemasaran. Edisi revisi. Penebar Swadaya, Jakarta 